\title{
LATE PHASE SPONTANEOUS PROLIFERATION OF CULTURED PERIPHERAL BLOOD LYMPHOCYTES ASSOCIATED WITH HTLV- I INFECTION: INVOLVEMENT OF CELLULAR RESPONSES AGAINST THE INFECTED CELLS
}

\author{
Shinji IJichi ${ }^{1}$, Koichi MACHIGAShira ${ }^{1}$, Masahiro NAGAI ${ }^{1}$ \\ Mitsuhiro OSAmE ${ }^{1}$ AND William W. HALL ${ }^{2}$ \\ Received June 26, 1996/Accepted July 29, 1996
}

\begin{abstract}
Common features of patients with human T lymphotropic virus type I (HTLV-I )-associated myelopathy/tropical spastic paraparesis (HAM/TSP) compared to asymptomatic HTLV-I carriers include a genetically determined high cellular immune responsiveness to HTLV- I and a distributional bias of viral activation between the blood flow and central nervous system (CNS). It had been proposed that increased and altered in vitro late phase spontaneous proliferation (SP) of peripheral blood lymphocytes, which is concomitant with in vitro viral activation, is associated with the pathogenesis of HAM/TSP. To assess whether SP might epitomize the peculiar cellular inflammation in the CNS of patients with HAM/ TSP, fractionated peripheral blood lymphocytes from HAM/TSP patients were employed to reconstitute this phenomenon in vitro. Although $\mathrm{CD} 8+$ cells had no inherent responsive potential in the absence of exogenous interleukin-2 (IL-2), the SP observed in CD4 + cell cultures was facilitated by the addition of autologous CD8 + cells to the cultures. It could be shown that proliferative responses of the CD $8+$ cells appeared against cultured and irradiated autologous CD4 + cells but not against purified HTLV- I virions. These findings clearly demonstrate that the cellular response against the infected cells is involved and is one of the major components of the late phase SP, and support the view that this phenomenon may represent an in vitro counterpart of the susceptibility to HAM/TSP.
\end{abstract}

Key words: Human T lymphotropic virus type I (HTLV-I ); HTLV-I -associated myelopathy/tropical spastic paraparesis (HAM/TSP); peripheral blood lymphocyte; spontaneous proliferation

\section{INTRODUCTION}

Spontaneous proliferation (SP) of peripheral blood mononuclear cells (PBMCs) is characterized by an increase in thymidine incorporation into the cells under culture conditions which are devoid of mitogenic stimuli. SP observed in the PBMCs cultured less than 3 days reflects the state of in vivo lymphocyte activation (Lane and Fauci, 1985; Griffin et al., 1989). This early phase $\mathrm{SP}$ has been reported in patients with a number of acute viral infections (measles, varicella, Epstein-Barr virus, and cytomegalovirus) (Griffin et al., 1989; Arneborn and
Biberfeld, 1983; Gavosto et al., 1959; Epstein and Brecher, 1965; Rinaldo Jr et al., 1977), in volunteers immunized with various bacterial or viral antigens (Crowther et al., 1969), in human immunodeficiency virus type 1 (HIV-I )-infected individuals (Lane and Fauci, 1985; deShazo et al., 1989), and in patients with multiple sclerosis (Brinkman et al., 1984). In contrast, late phase $\mathrm{SP}$, which is apparent on day 3 and peaks on days $5-7$, is one of the hallmarks of human T lymphotropic virus (HTLV) infection. This late phase SP had originally been described and attributed to an increase in large blastoid lymphocytes in cultures of PBMCs derived

1 Third Department of Internal Medicine, Faculty of Medicine, Kagoshima University, Sakuragaoka 8-35-1, Kagoshima 890, Japan

2 Laboratory of Medical Virology, The Rockefeller University, New York, NY 10021-6399, USA 
from HTLV - I -infected healthy donors (Yasuda et al., 1986). In patients with HTLV - I -associated myelopath$\mathrm{y} /$ tropical spastic paraparesis (HAM/TSP), a chronic neurological disorder characterized by signs of bilateral pyramidal tract lesions, the late phase SP was first referred to as "autologous proliferative response" or " spontaneous lymphoproliferative response" (Usuku et al.,1988; Jacobson et al., 1988). It could be demonstrated that the late phase SP is more intense in HAM/TSP patients than in asymptomatic HTLV-I carriers (Itoyama et al., 1988; Eiraku et al., 1992), and alterations in lymphocyte subset populations in the late phase SP were also noted in patients with HAM/TSP compared to asymptomatic carriers (Eiraku et al., 1992). Lymphocytes from HTLV-II carriers also exhibit late phase SP (Prince et al., 1990). However, the HTLV-II SP is significantly lower than that observed in HTLV-

I infection (Wiktor et al., 1991), and this may reflect molecular and biological differences (Prince et al., 1994) including their in vivo cellular tropism (Ijichi et al., 1992) between these closely related viruses which might be ultimately linked to the clinical outcomes in infected individuals (Hall et al., 1994).

In viro interactions between the virus and the cellular immune-responses in the late phase SP in HTLV- I infections have been suggested to be important (Usuku et al., 1988), and the HTLV-I activation could be demonstrated in cultured PBMCs derived from infected individuals (Hinuma et al., 1982; Minato et al., 1988). However, the role of cellular responses in the HTLV- I late phase SP remains poorly understood. To investigate this we have analyzed the in vitro response of $\mathrm{CD} 8+$ lymphocytes to cultured and irradiated autologous $\mathrm{CD} 4+$ cells from individuals with HAM/TSP.

\section{MATERIALS AND METHODS}

Patients.

A total of 6 patients who met WHO diagnostic criteria for HAM/TSP (WHO, 1989) and two HTLVI seronegative normal donors were studied. PBMCs were isolated from heparinized peripheral blood samples on density gradients using Ficoll-Hypaque, and the cells were viably cryopreserved in liquid nitrogen until tested using methods previously described (Usuku et al., 1988; Eiraku et al., 1992; Ijichi et al., 1995). Trypan blue dye exclusion tests demonstrated that the thawed PBMCs had a viability of more than $95 \%$.

Cell separations.

$\mathrm{T}$ cell subsets were prepared using a double-nega- tive selection procedure employing washed polystyrene magnetic beads coated with mouse monoclonal antibodies (mAbs) (Dynabeads; Dynal, Oslo, Norway). The thawed PBMCs were incubated with either anti-CD8 or CD4 mAb coated beads (20-25 beads/target cell) in phosphate buffered saline (PBS) containing $2 \%(\mathrm{v} / \mathrm{v})$ fetal calf serum(FCS) for $30 \mathrm{~min}$ at $4^{\circ} \mathrm{C}$ with gentle mixing. Rosetted cells were removed using a magnetic particle concentrator according to the manufacturer's instructions. The nonrosetted cells were collected and further purified by the second negative selection step using the same conditions as in the first step to obtain the $\mathrm{CD} 4+\mathrm{T}$ lymphocyte and $\mathrm{CD} 8+\mathrm{T}$ lymphocyte enriched cell populations respectively (CD4 + cells and $\mathrm{CD} 8+$ cells). The purity of the fractionated cell populations was confirmed by flow cytometric analysis where the maximum contamination of cells was $1.0 \%$.

\section{Cell cultures.}

The components of the late phase SP was reconstituted using fractionated viable cells. A series of graded mixtures of $\mathrm{CD} 4+$ and $\mathrm{CD} 8+$ cells from a patient with HAM/TSP was incubated for 7 days in RPMI-1640 supplemented with $100 \mathrm{U} / \mathrm{ml}$ penicillin, 100 $\mu \mathrm{g} / \mathrm{ml}$ streptomycin (GIBCO BRL), and $10 \%$ (v/v) FCS in 96-well U-bottom plates without any mitogenic stimuli (RPMI medium). Triplicate wells were used for each culture condition.

Responsive transformation of uninfected lymphocytes was evaluated as the proliferation of $\mathrm{CD} 8+$ cells responding to autologous irradiated CD4+ cells. The in vitro emergence of HTLV-I activation in the precultured $\mathrm{CD} 4+$ cells was previously demonstrated by detection of HTLV-I p19 and p24, increase in proviral and viral RNA amount, and using assays of reverse transcriptase activities in culture supernatants (Ijichi et al., 1995). As HTLV-I antigen presenting cells, CD4+ cells were obtained from a patient with $\mathrm{HAM} / \mathrm{TSP}$ and cultured for 10 days in RPMI medium containing $2 \mu \mathrm{g} / \mathrm{ml}$ phytohemagglutinin (PHA-P, Sigma, St. Louis, MO), and 10 I.U./ml interleukin-2 (IL-

2) (Genzyme, Cambridge, MA). The concentration of IL-2 was maintained by half medium changes every 3 days. Viable cells were isolated by density gradient centrifugation, washed with PBS, resuspended in RPMI medium and irradiated (5000 rad). The proliferative response of autologous $\mathrm{CD} 8+$ cells was evaluated by incubating triplicate wells containing $1.0 \times 10^{5} \mathrm{CD} 8+$ cells and the CD $4+$ cells $\left(1.0 \times 10^{5}\right)$ in 96 well plates in the presence $10 \mathrm{I}$.U./ml IL-2 for 3 to 7 days.

To compare the potential of purified virus virions 
with that of infected cells as the stimulant for CD8+ cells, $5.0 \times 10^{4}$ irradiated $\mathrm{CD} 4+$ cells prepared as described above (precultured for 13 days) or $8 \mu \mathrm{g} / \mathrm{ml}$ HTLV-I virions (EISAI, Tokyo, Japan) were added to autologous $\mathrm{CD} 8+$ cells $\left(5.0 \times 10^{4}\right)$ in 5 patients with HAM/TSP. The cells were incubated for 5 days in RPMI medium containing 10 I.U./ml IL-2 in triplicate wells. To assay the mitogenic effect of HTLV-I virions on normal cells, PBMCs and CD4 + cells isolated from two seronegative healthy donors were incubated for 5 days with $8 \mu \mathrm{g} / \mathrm{ml}$ virions in the absence of IL-2.

${ }^{3} \mathrm{H}$-thymidine incorporation assay.

Cultures were maintained at $37{ }^{\circ} \mathrm{C}$ in a $5 \% \mathrm{CO}_{2}$ atmosphere. The cells were pulsed with ${ }^{3} \mathrm{H}$-thymidine ( $\left[{ }^{3} \mathrm{H}\right] \mathrm{TdR} ; 37 \mathrm{kBq} /$ well) at $16 \mathrm{hr}$ before terminating the culture and then harvested on glass micro filter papers. Incorporated radioactivity was measured in a liquid scintillation counter (TRI-CARB-4430; Packard Instrument $\mathrm{CO}$. Inc., IL), and data are shown as the mean \pm SD. To evaluate the mitogenic activities of the purified virions and irradiated $\mathrm{CD} 4+$ cells, stimulation indices were calculated using the formula: mean cpm of cultures with stimulation/mean cpm of cultures without stimulation.

\section{RESULTS}

Reconstituted late phase SP (Fig. 1).

Cultured viable CD $4+$ cells $\left(3.0\right.$ and $1.0 \times 10^{5}$ cells/ well) obtained from a representative patient with HAM/TSP showed remarkable increase in $\left[{ }^{3} \mathrm{H}\right] \mathrm{TdR}$ incorporation without any mitogenic stimuli. In the absence of exogenous IL- 2 , the CD8 + cells $\left(3.0 \times 10^{5}\right.$ cells/well) from the same patient had no proliferative response without viable $\mathrm{CD} 4+$ cells. However, the increase in $\left[{ }^{3} \mathrm{H}\right] \mathrm{TdR}$ incorporation observed in $\mathrm{CD} 4+$ cell cultures was facilitated by the addition of autologous $\mathrm{CD} 8+$ cells $\left(2.5 \times 10^{4}\right.$ to $2.0 \times 10^{5}$ cells/ well) in a dose dependent manner, showing that the extraordinary excess of CD8 + cell population (at 0.5 of the $\mathrm{CD} 4+/ \mathrm{CD} 8+$ cell ratio) induces the greatest facilitation in cell proliferation in these conditions.

Proliferative response of CD8 + cells against irradiated autologous $\mathrm{CD} 4+$ cells.

In contrast to the transformation of $\mathrm{CD} 4+$ cells, the proliferative response of $\mathrm{CD} 8+$ cells to autologous HTLV-I -infected cells was not concomitant with the induction of HTLV- I antigens in the proliferating cells (Ijichi et al., 1995). Preliminary studies have demonstrated that the in vitro proliferation of $\mathrm{CD} 8+$ cells depends on the presence of viable $\mathrm{CD} 4+$ cells $\mathrm{co}^{-}$cultured, which include infected cells and may be supplying growth factors, and the $\mathrm{CD} 8+$ cell response against irradiated $\mathrm{CD} 4+$ cells requires preincubation of the CD4 + cells and supplementation of exogenous IL-2 in the medium (Ijichi et al., 1995; Nagai et al., 1995). Because IL-2-induced proliferation of the CD8+ cells (alone) varies according to the in vivo expression of IL2 receptors on the cells (Ijichi et al., 1995; Nagai et al., 1995), the responsive proliferation was assessed as stimulation indices. To analyze the proliferative response of uninfected $\mathrm{CD} 8+$ cells against autologous infected cells, the proliferative potential of $\mathrm{CD} 8+$ cells cocultured with precultured and irradiated $\mathrm{CD} 4+$ cells was inves-

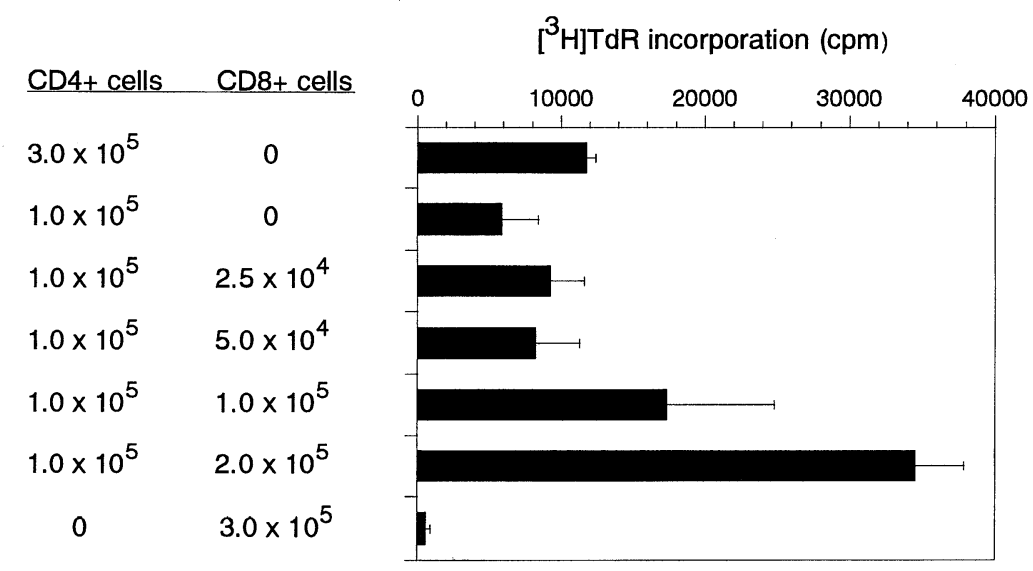

Figure 1. Reconstituted cultures to show the each role of $\mathrm{CD} 4+$ cells and CD8 + cells for the HTLV-I late phase SP. Fractionated viable cells were cultured in the absence of IL- 2 for 7 days. The results are expressed as the means \pm SD in triplicate cultures. 


\begin{tabular}{|c|c|c|c|c|c|c|}
\hline \multirow[t]{2}{*}{ CD8+ cells } & \multirow[t]{2}{*}{$\begin{array}{l}\text { Irradiated } \\
\text { CD4+ cells }\end{array}$} & \multirow[t]{2}{*}{$\begin{array}{l}\text { Culture } \\
\text { duration (days) }\end{array}$} & \multicolumn{4}{|c|}{$\left[{ }^{3} \mathrm{H}\right] \mathrm{TdR}$ incorporation (cpm) } \\
\hline & & & 0 & 3000 & 6000 & 9000 \\
\hline $1.0 \times 10^{5}$ & 0 & 3 & & & & \\
\hline $1.0 \times 10^{5}$ & 0 & 5 & F & & & \\
\hline $1.0 \times 10^{5}$ & 0 & 7 & F & & & \\
\hline 0 & $1.0 \times 10^{5}$ & 3 & & & & \\
\hline 0 & $1.0 \times 10^{5}$ & 5 & 1 & & & \\
\hline 0 & $1.0 \times 10^{5}$ & 7 & 1 & & & \\
\hline $1.0 \times 10^{5}$ & $1.0 \times 10^{5}$ & 3 & & & & \\
\hline $1.0 \times 10^{5}$ & $1.0 \times 10^{5}$ & 5 & & & & \\
\hline $1.0 \times 10^{5}$ & $1.0 \times 10^{5}$ & 7 & & & & \\
\hline
\end{tabular}

Figure 2. CD8 + cell response against the autologous irradiated CD4 + cells (precultured) in the presence of exogenous IL-2. The results are expressed as the means \pm SD in triplicate cultures.

tigated (Fig. 2). The representative case in Fig. 2 is HAM3 in Table 1, whose CD8+ cells alone did not exhibit high incorporation of thymidine in the presence of exogenous IL-2. Control cultures showed low $\left[{ }^{3} \mathrm{H}\right]$ $\mathrm{TdR}$ incorporation into the viable $\mathrm{CD} 8+$ cells and the irradiated CD $4+$ cells cultured alone for 3 to 7 days in

Table 1 Cell responses against purified HTLV-I virions or irradiated autologous $\mathrm{CD} 4+$ cells possessing HTLV-I antigens

\begin{tabular}{|c|c|c|}
\hline \multirow[b]{2}{*}{ Cells } & \multicolumn{2}{|c|}{$\left[{ }^{3} \mathrm{H}\right]$ TdR incorporation (cpm) into cells stimulated by } \\
\hline & Purified HTLV-I virions & Irradiated CD $4+$ cells \\
\hline \multicolumn{3}{|c|}{ (Cultures in the absence of IL-2) } \\
\hline $\begin{array}{l}\text { ND1 PBMCs } \\
5.0 \times 10^{4}\end{array}$ & $2539 \pm 556(\underline{7.7})$ & n.d. \\
\hline $\begin{array}{l}\text { ND2 PBMCs } \\
5.0 \times 10^{4}\end{array}$ & $8077 \pm 1221(\underline{16.3})$ & n.d. \\
\hline $\begin{array}{l}\text { ND1 CD } 4+\text { cells } \\
1.0 \times 10^{5}\end{array}$ & $24207 \pm 13183(\underline{69.8})$ & n.d. \\
\hline $\begin{array}{l}\text { ND2 CD4 + cells } \\
1.0 \times 10^{5}\end{array}$ & $16412 \pm 4529(\underline{61.2})$ & n.d. \\
\hline \multicolumn{3}{|c|}{ (Cultures in the presence of $\mathrm{IL}-2$ ) } \\
\hline $\begin{array}{l}\text { ND1 CD8 }+ \text { cells } \\
1.0 \times 10^{5}\end{array}$ & $24311 \pm 1141(0.8)$ & n.d. \\
\hline $\begin{array}{l}\text { ND2 CD8 }+ \text { cells } \\
1.0 \times 10^{5}\end{array}$ & $52756 \pm 7780(0.9)$ & n.d. \\
\hline $\begin{array}{l}\text { HAM1 CD8 + cells } \\
5.0 \times 10^{4}\end{array}$ & $4553 \pm 439(1.0)$ & $31232 \pm 5148(\underline{7.2})$ \\
\hline $\begin{array}{l}\text { HAM2 CD8 + cells } \\
5.0 \times 10^{4}\end{array}$ & $22516 \pm 3794(0.8)$ & $60394 \pm 5007(\underline{2.0})$ \\
\hline $\begin{array}{l}\text { HAM3 CD8 }+ \text { cells } \\
5.0 \times 10^{4}\end{array}$ & $1956 \pm 510(1.1)$ & $17723 \pm 2539(\underline{10.1})$ \\
\hline $\begin{array}{l}\text { HAM4 CD8 + cells } \\
5.0 \times 10^{4}\end{array}$ & $5714 \pm 1884(1.0)$ & $11799 \pm 470(\underline{2.0})$ \\
\hline $\begin{array}{l}\text { HAM5 CD8 + cells } \\
5.0 \times 10^{4}\end{array}$ & $22178 \pm 3177(0.8)$ & $45531 \pm 3227(\underline{1.7})$ \\
\hline
\end{tabular}

The results are expressed as the means \pm SD (stimulation indices) in triplicate cultures. Significant stimulation indices are underlined. Abbreviations: ND1 and ND2, normal donors; HAM1-HAM5, patients with HAM/TSP; n. d., not done. 
this patient. The CD8+ cells cocultured with the irradiated autologous CD4 + cells exhibited an increase in thymidine incorporation, and the proliferation of CD8 + cells was found to be most remarkable in late phase of culture (day 7).

The late phase responsive proliferation of the CD8 + cells cocultured with irradiated autologous $\mathrm{CD} 4+$ cells was confirmed in a total of 5 patients with HAM/TSP (Table 1 and Figure 2). Cell free purified HTLV- I virions were found to have mitogenic activity on normal donor PBMCs and CD4 + cells. However, the stimulation index data demonstrated that the virions had essentially no stimulatory effect on the CD8 + cells in these patients (Table 1). The quantity of purified virus virions employed $(8 \mu \mathrm{g} / \mathrm{ml})$ was found to be optimal to activate normal donor PBMCs (data not shown).

\section{DISCUSSION}

Although HTLV- I antigens have a variety of viroimmunological properties as a mitogen, a transactivator, and antigens, the infection is characterized by the viral latency in circulating infected cells in the host (Schüpbach, 1989). Peripheral blood lymphocytes obtained from HTLV-I -infected individuals exhibit late phase SP accompanied by in vitro HTLV- I activation, and patients with HAM/TSP are characterized by high and altered late phase SP as mentioned above. Because purified $\mathrm{T}$ lymphocytes can exhibit the late phase SP, this phenomenon is different from the autolegous mixed lymphocyte reaction (AMLR) (Minato et al., 1989; Lal et al., 1992), and recently, the HTLV-I SP has been reported as a T cell colonyforming cell abnormality (Lunardi-1skandar et al., 1993). In vitro spontaneous expression of HTLV-I RNA and viral antigens in cultured PBMCs has been demonstrated in healthy HTLV- I carriers and patients with HAM/TSP (Hinuma et al., 1982; Minato et al., 1988; Mann et al., 1994), and HTLV-I viral particles have been demonstrated in extracellular spaces of cul tured PBMCs (Gessain and Gout, 1992). As such, the IL2-independent growth of infected clones (Höllsberg et al., 1992), mitogenic activity of HTLV-I virions (Gazzolo and Dodon, 1987; Dodon and Gazzolo, 1987; Dodon et al., 1989; Maguer et al., 1993; Cassé et al., 1994), and T cell activation induced by cell-to-cell contact with the infected cells (Wucherpfennig et al., 1992; Kimata et al., 1993) may be involved in the HTLV - I SP. The mitogenic activity of HTLV-I virions and the mitogenic surface structure(s) on HTLV- I -infect- ed cells requires the $\mathrm{CD} 2 /$ lymphocyte function-associated antigen 3 (LFA-3) pathway for the activation of responder T cells (Dodon et al., 1989; Wucherpfennig et al., 1992; Kimata et al., 1993), and the subsequent autocrine or paracrine secretion of IL-2 from responding cells is essential for cell proliferation (Dodon and Gazzolo, 1987; Wucherpfennig et al., 1992). In addition, it has been suggested that other soluble factors may contribute to the SP (Lal and Rudolph, 1991; Lal et al., 1991). Other studies have suggested that responsive $T$ cell proliferation in HTLV-I SP may be a human lymphocyte antigen (HLA) haplotype-linked response against HTLV-I virions (Usuku et al., 1988; Sonoda, 1990), and it had been suggested that an inhibitory effect of $\mathrm{CD} 8+$ cells on the in vitro HTLV-I expression in infected autologous CD4+ cells is a HLA haplotypelinked response (Sonoda, 1990). Moreover, cell responses in HTLV- I SP have recently been shown to involve a different signal transduction pathway from the growth of HTLV-I -infected cells (Mann et al., 1994). Therefore, the proliferation of CD8 + cells in the HTLVI SP has received much attention as an in vitro epitome of the cellular inflammation in the central nervous system (CNS) of HAM/TSP patients (Eiraku et al., 1992), and the view supports the proposed implication of the anti-HTLV-I cytotoxic T lymphocytes in the pathogenesis of HAM/TSP (Moore et al., 1989; Jacobson et al., 1990).

In the present study we could demonstrate the following. (i) Not only the in vitro activation of infected $\mathrm{CD} 4+$ cells but also the proliferative response of $\mathrm{CD} 8+$ cells against infected cells is involved and is one of the major components of the HTLV-I late phase SP. (ii) The presence of viable $\mathrm{CD} 4+$ cells is critical for the HTLV-I virion-related T cell activation. (iii) The $\mathrm{CD} 8+$ cell response to infected cells requires either the presence of viable CD4 + cells or exogenous IL-2.

The HTLV-I late phase SP might bear an important relationship to the observed cellular inflammation in situ around HTLV- I -infected cells in HAM/TSP, and may be involved in the critical pathological process of this disorder (Ijichi et al., 1993). Although it has been extremely difficult to detect HTLV-I antigens in the affected tissues of patients (Gessain and Gout, 1992), the presence of integration and activation of HTLV-I in the CNS of HAM/TSP patients has been demonstrated by in situ hybridization techniques (Hara et al., 1994; Kashio et al., 1994; Kuroda et al., 1994; Lehky et al., 1995). The cell responses involved in the HTLV- I late phase SP presented here may be an in vitro equivalent of the cellular inflammation in the affected tissues in 
patients with HTLV-I -associated diseases.

\section{REFERENCES}

1 ) Arneborn, P. and Biberfeld, G. (1983): T-lymphocyte subpopulation in relation to immunosuppression in measles and varicella. Infect. Immun., 39, 29-37

2 ) Brinkman, C.J.J., Nillesen, W.M. and Hommes, O.R. (1984): Lymphocyte subpopulations in multiple sclerosis: spontaneous and mitogen-induced activity. Clin. Immunol. Immunopathol. 31, 364-370

3 ) Cassé, H., Girerd, Y., Gazzolo, L. and Dodon, M.D. (1994): Critical involvement of human $\mathrm{T}$ cell leukaemia virus type I virions in mediating the viral mitogenic effect. J. Gen. Virol., 75, 1909-1916

4 ) Crowther, D., Fairley, G.H. and Sewell, R.L. (1969): Lymphoid cellular responses in the blood after immunization in man. J. Exp. Med., 129, 849-869

5 ) deShazo, R.D., Morgan, J.E., Daul, C.B., Andes, A., Hyslop, N. and Palmer, C. (1989): Studies of spontaneous proliferation of mononuclear cells in human immunodeficiency virus (HIV- I )-infected individuals. J. Allergy Clin. Immunol., 84, 34-39

6 ) Dodon, M.D. and Gazzolo, L. (1987): Loss of interleukin -2 requirement for the generation of $T$ colonies defines an early event of human T-lymphotropic virus type I infection. Blood 69, 12-17

7 ) Dodon, M.D., Bernard, A. and Gazzolo, L. (1989): Peripheral $\mathrm{T}$-lymphocyte activation by human $\mathrm{T}$-cell leukemia virus type I interferes with the CD2 but not with the CD3/TCR pathway. J. Virol., 63, 5413-5419

8 ) Eiraku, N., Ijichi, S., Yashiki, S., Osame, M. and Sonoda, S. (1992): Cell surface phenotype of in vitro proliferating lymphocytes in HTLV-I -associated myelopathy. J. Neuroimmunol., 37, 223-228

9 ) Epstein, L.B. and Brecher, G. (1965): DNA and RNA synthesis of circulating atypical lymphocytes in infectious mononucleosis. Blood 25, 197-203

10) Gavosto, F., Pileri, A. and Maraini, G. (1959): Incorporation of thymidine labeled with tritium by circulating cells of infectious mononucleosis. Nature 183, 1691-1692.

11) Gazzolo, L. and Dodon, M.D. (1987): Direct activation of resting $\mathrm{T}$ lymphocytes by human $\mathrm{T}$-lymphotropic virus type I. Nature 326, 714-717

12) Gessain, A. and Gout, O. (1992): Chronic myelopathy associated with human T-lymphotropic virus type I (HTLV- I ). Ann. Int. Med., 117, 933-946

13) Griffin, D.E., Ward, B.J., Jauregui, E., Johnson, R.T. and Vaisberg, A. (1989): Immune activation in measles. N. Engl. J. Med., 320, 1667-1672

14) Hall, W.W., Kubo, T., Ijichi, S., Takahashi, H. and Zhu, S.W. (1994): Human T cell leukemia/lymphoma virus, type II (HTLV-II): emergence of an important newly recognized pathogen. Semin. Virol., 5 165-178

15) Hara, H., Morita, M., Iwaki, T., Hatae, T., Itoyama, Y., Kitamoto, T., Akizuki, S., Goto, I. and Watanabe, T.
(1994): Detection of human T lymphotropic virus type I (HTLV- I ) proviral DNA and analysis of T cell receptor V $\beta$ CDR3 sequences in spinal cord lesions of HTLV - I -associated myelopathy/tropical spastic paraparesis. J. Exp. Med., 180, 831-839

16) Hinuma, Y., Gotoh, Y., Sugamura, K., Nagata, K., Goto, T., Nakai, M., Kamada, N., Matsumoto, T. and Kinoshita, K. (1982): A retrovirus associated with human adult T-cell leukemia: in vitro activation. Jpn. J. Cancer. Res. (Gann) 73, 341-344

17) Höllsberg, P., Wucherpfennig K. W., Ausubel, L.J.,Calvo, V., Bierer B. E. and Hafler, D.A. (1992): Characterization of HTLV-I in vivo infected T cell clones: IL-2independent growth of nontransformed T cells. J. Immunol., 148, 3256-3263

18) Ijichi, S., Ramundo, M.B., Takahashi, H. and Hall, W.W. (1992): In vivo cellular tropism of human T cell leukemia virus type II (HTLV-II). J. Exp. Med., 176, 293-296

19) Ijichi, S., Izumo, S., Eiraku, N., Machigashira, K., Kubota, R., Nagai, M., Ikegami, N., Kashio, N., Umehara, F., Maruyama, I. and Osame, M. (1993): An autoaggressive process against bystander tissues in HTLV- I -infected individuals: a possible pathomechanism of HAM/TSP. Med. Hypoth., 41, 542-547

20) Ijichi, S., Izumo, S., Nagai, M., Shinmyozu, K., Hall, W. W. and Osame, M. (1995): Antiviral and immunomodulatory effects of interferon-a on cultured lymphocytes from patients with HTLV-I -associated myelopathy (HAM/TSP). J. Neuroimmunol., 61, 213220

21) Itoyama, Y., Minato, S., Kira, J., Goto, I., Sato, H., Okochi, K. and Yamamoto, N. (1988): Spontaneous proliferation of peripheral blood lymphocytes increased in patients with HTLV- I -associated myelopathy. Neurology 38, 1302-1307

22) Jacobson, S., Zaninovic, V., Mora, C., Rodgers-Johnson, P., Sheremata, W.A., Gibbs, C.J., Gajdusek, C. and MacFarlin, D.E. (1988): Immunological findings in neurological diseases associated with antibodies to HTLV$\mathrm{I}$ : activated lymphocytes in tropical spastic paraparesis. Ann. Neurol., 23 (Suppl.), S196-S200

23) Jacobson, S., Shida, H., McFarlin, D.E., Fauci, A.S. and Koenig, S. (1990): Circulating CD8 + cytotoxic T lymphocytes specific for HTLV-I pX in patients with HTLV-I associated neurological disease. Nature 348, 245-248

24) Kashio, N., Izumo, S., Ijichi, S., Hashimoto, K., Umehara, F., Higuchi, I. and Osame, M. (1994): Detection of HTLV-I provirus by in situ polymerase chain reaction in mononuclear cells infiltrating spinal cord lesions from HAM/TSP patients. Brain. Pathol., 4, 498 (abstract).

25) Kimata, J.T., Palker, T.J. and Ratner, k. (1993): The mitogenic activity of human T-cell leukemia virus type $\mathrm{I}$ is $\mathrm{T}$-cell associated and requires the CD2/LFA-3 activation pathway. J. Virol., 67, 3134-3141

26) Kuroda, Y., Matsui, M., Kikuchi, M., Kurohara, K., Endo, 
C., Yukitake, M., Matsuda, Y., Tokunaga, O., KomineSakaki, A. and Kawaguchi, R. (1994): In sutu demonstration of the HTLV- I genome in the spinal cord of a patient with HTLV-I -associated myelopathy. Neurology 44, 2295-2299

27) Lal, R.B. and Rudolph, D.L. (1991): Constitutive production of interleukin- 6 and tumor necrosis factor- $\alpha$ from spontaneously proliferating $\mathrm{T}$ cells in patients with human T-cell lymhotropic virus type- I /II. Blood 78, 571-574

28) Lal, R.B., Rudolph, D.L., Folks, T.M. and Hooper, C. (1991): Role of insulin-like growth factor-1 in spontaneous proliferation of HTLV- I -infected lymphocytes. J. Acquir. Immune Defic. Syndr., 4, 1165-1166

29) Lal, R.B., Hjelle, B. and Rudolph, D.L. (1992): Spontaneous proliferation of HTLV-II-infected peripheral blood lymphocytes: HLA - DR - driven, IL - 2-dependent response. Microbiol. Immunol., 36, 865-872

30) Lane, H.C. and Fauci, S. (1985): Immunologic abnormalities in the acquired immunodeficiency syndrome. Annu. Rev. Immunol., 3, 477-500

31) Lehky, T.J., Fox, C.H., Koenig, S., Levin, M.C., Flerlage, N., Izumo, S., Sato, E., Raine, C.S., Osame, M. and Jacobson, S. (1995): Detection of human Tlymphotropic virus type I (HTLV-I) tax RNA in the central nervous system of HTLV-I - associated myelopathy/tropical spastic paraparesis patients by in situ hybridization. Ann. Neurol., 37, 167-175

32) Lunardi-Iskandar, Y., Gessain, A., Lam, V.H. and Gallo, R.C. (1993): Abnormal in vitro proliferation and differentiation of $\mathrm{T}$ cell colony-forming cells in patients with tropical spastic paraparesis/human $\mathrm{T}$ lymphocyte virus type I (HTLV-I )-associated myeloencephalopathy and healthy HTLV- I carriers. J. Exp. Med., 177, 741750

33) Maguer, V., Cassé-Ripoll, H., Gazzolo, L. and Dodon, M. D. (1993): Human T-cell leukemia virus type I-induced proliferation of human immature $\mathrm{CD} 2+\mathrm{CD} 3-$ thymocytes. J. Virol., 69,5529-5537

34) Mann, D.L., Martin, P., Hamlin-Green, G., Nalewalk, R. and Blattner, W. (1994): Virus production and spontaneous cell proliferation in HTLV - I - infected lymphocytes. Clin. Immunol. Immunopathol., 72, 312-320

35) Minato, S., Itoyama, Y., Goto, I. and Yamamoto, N. (1988): Expression of HTLV-I antigen in cultured peripheral blood mononuclear cells from patients with HTLV-I associated myelopathy. J. Neurol. Sci., 87, 233 $-244$

36) Minato, S., Itoyama, Y., Fujii, N., Kira, J., Goto, I. and Yamamoto, N. (1989): Activated T cells in HTLV- Iassociated myelopathy: autologous mixed lymphocyte reaction. Ann. Neurol., 26, 398-401

37) Moore, G.R.W., Traugott, U., Scheinberg, L.C. and Raine, C.S. (1989): Tropical spastic paraparesis: a model of virus-induced, cytotoxic T-cell-mediated demyelination? Ann. Neurol., 26, 523-530

38) Nagai, M., Ijichi, S., Hall, W.W. and Osame, M. (1995): Differential effect of $\mathrm{TGF}-\beta \mathrm{l}$ on the in vitro activation of HTLV-I and the proliferative response of CD8 $+\mathrm{T}$ lymphocytes in patients with HTLV-I-associated myelopathy (HAM/TSP). Clinical Immunol. Immunopathol., 77, 324-331

39) Prince, H., Kleinman, S., Doyle, M., Lee, H. and Swanson, P. (1990): Spontaneous lymphocyte proliferation in vitro characterized both HTLV-I and HTLVII infection. J. Acquir, Immune Defic. Syndr., 3, 11991200

40) Prince, H.E., Golding, J. and York, J. (1994): Lymphocyte subset alterations associated with increased spontaneous lymphocyte proliferation in human T lymphotropic virus (HTLV) infection: distinctive patterns for HTLV-I versus HTLV-I I infection. J. Infect. Dis., 169, 1409-1410

41) Rinaldo, Jr., C.R., Black, P.H. and Hirsch, M.S. (1977): Interaction of cytomegalovirus with leukocytes from patients with mononucleosis due to cytomegalovirus. J. Infect. Dis., 136, 667-678

42) Schüpbach, J. (1989): Introduction and history. In: R.W. Compans et al. (Eds.), Human Retrovirology: Facts and Concepts (Current Topics in Microbiology and Immunology 142), Springer-Verlag, Berlin, 1-5

43) Sonoda, S. (1990): Genetic and immunologic determinants of HTLV- I -associated diseases. In: W.A. Blattner (Ed.), Human Retrovirology: HTLV. 315-326, Raven, New York, NY

44) Usuku, K., Sonoda, S., Osame, M., Yashiki, S., Takahashi, K., Matsumoto, M., Sawada, T., Tsuji, K., Tara, M. and Igata, A. (1988): HLA haplotype-linked high immune responsiveness against HTLV-I in HTLV-I -associated myelopathy: comparison with adult $\mathrm{T}$-cell leukemia/lymphoma. Ann. Neurol., 23 (Suppl.), 143-150

45) Wiktor, S.Z., Jacobson, S., Weiss, S.H., Shaw, G.M., Reuben, J.S., Shorty, V.J., McFarlin, D.E. and Blattner, W.A. (1991): Spontaneous lymphocyte proliferation in HTLV-II infection. Lancet 337, 327-328

46) World Health Organization (1989): Virus diseases. human T-lymphotropic virus type I, HTLV-I (abstract). WHO Weekly Epidemiol. Rec., 49, 382-383

47) Wucherpfennig, K.W., Höllsberg, P., Richardson, J. H., Benjamin, D. and Hafler, D.A. (1992): T-cell activation by autologous human $\mathrm{T}$-cell leukemia virus type I -infected T-cell clones. Proc. Natl. Acad. Sci., USA 89, 2110-2114

48) Yasuda, K., Sei, Y., Yokoyama, M.M., Tanaka, K. and Hara, A. (1986): Healthy HTLV-I carriers in Japan: the haematological and immunological characteristics. Br. J. Haematol., 64, 195-203 